\title{
Assessment of the Reptilian Fauna in the Brahmaputra Plains of Two Districts in Assam, India
}

\author{
Debaprasad Sengupta ${ }^{1}$, Chandra Gupta Borah ${ }^{2}$, and Jyotima Phukon ${ }^{2}$ \\ ${ }^{1}$ Wildlife Institute of India, Dehradun-248001, Uttarakhand, India (debaprasad.sengupta40@hotmail.com) \\ ${ }^{2}$ Department of Zoology, Dibru College, Dibrugarh-786002, Assam, India
}

Tndia is one of the top twelve nations of the world in terms 1 of mega-biodiversity, boasting a rich reptilian fauna represented by 506 currently recognized species (Das 2003), of which 199 are lizards (Venugopal 2010). Reptiles occupy a diverse range of both natural and human-altered habitats and microhabitats.

Seven states in northeastern India are popularly known as the "seven sisters." The total forest cover in this region is

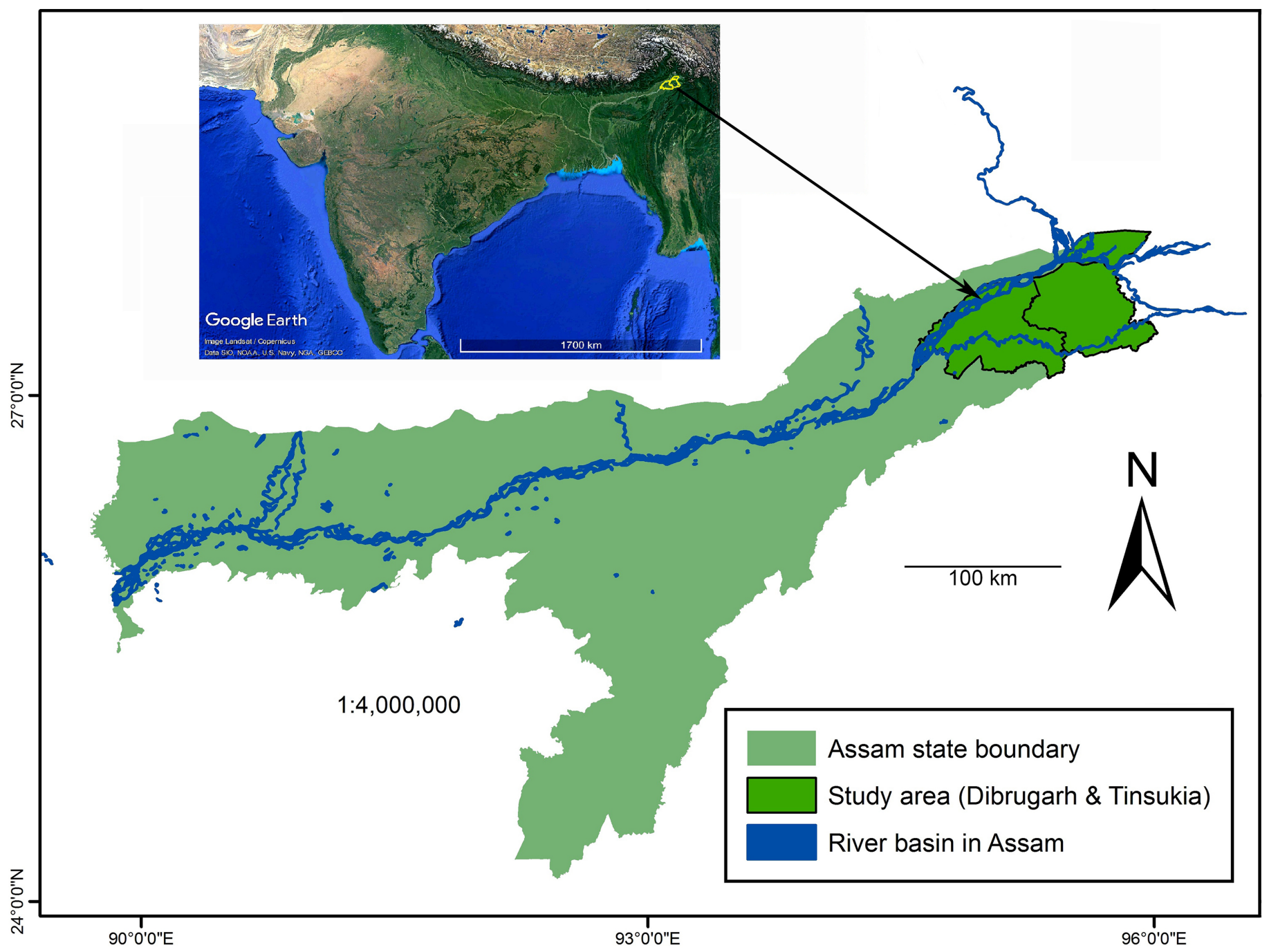

Fig. 1. The study area in the Dibrugarh and Tinsukia Districts of Assam, India. 
Table 1. Species recorded during the survey period with IUCN Red List status (IUCN) and national status according to the Wildlife Protection Act of 1972 (WPA).

\begin{tabular}{|c|c|c|c|c|}
\hline Family & Scientific Name and Authority & Common Name & IUCN & WPA \\
\hline \multirow[t]{2}{*}{ Agamidae } & Calotes versicolor (Daudin 1802) & Indian Garden Lizard & Not Assessed & Not Listed \\
\hline & Cristidorsa planidorsata (Jerdon 1870) & Smooth-scaled Mountain Lizard & Not Assessed & Not Listed \\
\hline \multirow[t]{3}{*}{ Gekkonidae } & Hemidactylus frenatus Dumeril \& Bibron 1836 & Common House Gecko & Not Assessed & Not Listed \\
\hline & Hemidactylus flaviviridis Rüppell 1835 & Northern House Gecko & Not Assessed & Not Listed \\
\hline & Gekko gecko (Linnaeus 1758) & Tokay Gecko & Not Assessed & Schedule-IV \\
\hline \multirow[t]{2}{*}{ Mabuyidae } & Eutropis multifasciata (Kuhl 1820) & Many-lined Sun Skink & Not Assessed & Not Listed \\
\hline & Eutropis macularia (Blyth 1853) & Bronze Skink & Not Assessed & Not Listed \\
\hline & Argyrophis diardii (Schlegel 1839) & Diard's Blindsnake & Not Assessed & Schedule-IV \\
\hline Pythonidae & Python bivittatus Kuhl 1820 & Burmese Python & Vulnerable & Schedule-I \\
\hline \multirow[t]{3}{*}{ Colubridae } & Lycodon aulicus (Linnaeus 1758) & Common Wolf Snake & Not Assessed & Schedule-IV \\
\hline & Ptyas mucosa (Linnaeus 1758) & Oriental Ratsnake & Not Assessed & Schedule-II \\
\hline & Coelognathus radiatus (Boie 1827) & Copper-headed Trinket Snake & Not Assessed & Schedule-IV \\
\hline \multirow[t]{3}{*}{ Natricidae } & Xenochrophis piscator (Schneider 1799) & Checkered Keelback & Not Assessed & Schedule-II \\
\hline & Rhabdophis subminiatus (Schlegel 1837) & Red-necked Keelback & Vulnerable & Schedule-IV \\
\hline & Amphiesma stolatum (Linnaeus 1758) & Buff-striped Keelback & Not Assessed & Schedule-IV \\
\hline & Ophiophagus hannah (Cantor 1836) & King Cobra & Vulnerable & Schedule-II \\
\hline Viperidae & Daboia russelii (Shaw \& Nodder 1797) & Russel's Viper & Not Assessed & Schedule-IV \\
\hline \multirow[t]{4}{*}{ Geomydidae } & Geoclemys hamiltonii (Gray 1831) & Spotted Pond Turtle & Vulnerable & Schedule-I \\
\hline & Pangshura sylhetensis Jerdon 1870 & Assam Roofed Turtle & Endangered & Schedule-I \\
\hline & Pangshura tecta (Gray 1831) & Indian Roofed Turtle & Not Assessed & Schedule-I \\
\hline & Pangshura tentoria (Gray 1834) & Indian Tent Turtle & Not Assessed & Not Listed \\
\hline \multirow[t]{2}{*}{ Trionychidae } & Nilssonia gangetica (Cuvier 1825) & Ganges Softshell Turtle & Vulnerable & Schedule-I \\
\hline & Lissemys punctata (Bonnaterre 1790) & Indian Flapshell Turtle & Least Concern & Schedule-I \\
\hline
\end{tabular}

$164,043 \mathrm{~km}^{2}$, which represents $25 \%$ of the total forest cover of India (FSI 1997). The region can be broadly differentiated into the Eastern Himalayan (Olson and Dinerstein 2002) to the north, the Northeastern Hills (Meghalaya and Mizoram-Manipur Kachin forest zones) to the south, and the Brahmaputra River Basin (BRB) separating the two (Mani 1974). Our study area (Fig. 1) consisted of the
Municipal Area of Dibrugarh District with an area of about $15.5 \mathrm{~km}^{2}\left(27^{\circ} 27^{\prime} 0 " \mathrm{~N}-27^{\circ} 31^{\prime} 20^{\prime \prime} \mathrm{N}\right.$ x 94 $\left.52^{\circ} 0 " \mathrm{E}-94^{\circ} 57^{\prime} 0 " \mathrm{E}\right)$ and the Municipal Area of Tinsukia District with an area of about $10.54 \mathrm{~km}^{2}\left(95^{\circ} 19^{\prime} 20.00^{\prime \prime E}-95^{\circ} 24^{\prime} 00.00^{\prime \prime E ~ x ~}\right.$ $\left.27^{\circ} 31^{\prime} 20.00^{\prime \prime} \mathrm{N}-27^{\circ} 28^{\prime} 80.00^{\prime \prime} \mathrm{N}\right)$.

From September 2012 to August 2017, we engaged in Visual Encounter Surveys (VES), supplemented with a thor- 
ough review of the relevant literature and reliable photographic records, to record the reptilian species diversity. Active searches involving turning rocks and logs, peeling bark, and digging through leaf litter. Turtles were recorded on the basis of bycatches by fishermen and also by active searches along river banks and sacred temple ponds. For each observation, we recorded data on locality using a Garmin GPS 12, noted habitat, microhabitat, and the presence of sympatric species (if any), employed morphometric data and keys in Smith (1935, 1943), Das (2002), and Daniel (2002) to confirm the identities of species, and released animals at their respective capture sites. We also spoke with local residents to make them aware of the local reptilian fauna and to supplement field observations.

We recorded 34 species in 27 genera and 14 families during the survey period (Table 1). The most commonly encountered lizard species was Hemidactylus frenatus, whereas Gekko gecko and Cristidorsa planidorsata were extremely rare and had patchy distributions. Lycodon aulicus and Ptyas mucosus were the most frequently sighted snakes, whereas Rhabdophis subminiatus was sighted only three times during the entire study period. Among turtles, Lissemys punctata was frequently recorded in the Dibrugarh Municipal Drain and in ponds in the vicinity of the Brahmaputra River.

\section{Acknowledgements}

We thank the Department of Zoology, Dibru College for providing an opportunity to carry out our work. We also thank the Assam Forest Department and DFO of the Dibrugarh and Tinsukia Districts for their support.

\section{Literature Cited}

Daniel, J.C. 2002. The Book of Indian Reptiles and Amphibians. Bombay Natural History Society and Oxford University Press, Mumbai.

Das, I. 2002. Snakes and other Reptiles of India. New Holland, London, UK.

Das, I. 2003. Growth of knowledge on the reptiles of India, with an introduction to systematics, taxonomy and nomenclature. Journal of the Bombay Natural History Society 100: 446-501.

FSI (Forest Survey of India). 1999. State of forest report 1999. Forest Survey of India (Ministry of Environment and Forests), Dehra Dun < http://fsi.nic.in/ documents/sfr_1999_hindi.pdfs.

Mani, M.S. 1974. Ecology and Biogeography in India. Dr. W. Junk B.V. Publishers, The Hague, The Netherlands.

Olson, D. and E. Dinerstein. 2002. The Global 200: Priority ecoregions for global conservation. Annals of the Missouri Botanical Garden 89: 199-224.

Smith, M.A. 1935. The Fauna of British India, Ceylon and Burma, Including the Whole of the Indo-Chinese Sub-region. Reptilia and Amphibia. Vol. II. Sauria. Taylor and Francis, London, UK.

Venugopal, P.D. 2010. An updated and annotated list of Indian lizards (Reptilia: Sauria) based on a review of distribution records and checklists of Indian reptiles. Journal of Threatened Taxa 2: 725-738. 